https://helda.helsinki.fi

\title{
Therapeutic conversation
}

\section{Voutilainen, Liisa}

John Benjamins

2014

Voutilainen , L \& Peräkylä , A 2014 , Therapeutic conversation . in J-O Östman \& J

Verschueren (eds) , Handbook of Pragmatics . John Benjamins , Amsterdam . https://doi.org/10.1075/hop.18.the1

http://hdl.handle.net/10138/153417

https://doi.org/10.1075/hop.18.the1

acceptedVersion

Downloaded from Helda, University of Helsinki institutional repository.

This is an electronic reprint of the original article.

This reprint may differ from the original in pagination and typographic detail.

Please cite the original version. 
Liisa Voutilainen and Anssi Peräkylä

\section{THERAPEUTIC CONVERSATION}

Forthcoming in: Jan-Ola Östman and Jef Verschueren (eds.) Handbook of pragmatics, John Benjamins 


\section{Therapeutic conversation}

\section{Liisa Voutilainen and Anssi Peräkylä}

Psychotherapeutic conversation is a specific form of institutional talk (see Drew and Heritage 1992, and Heritage and Clayman 2010, for a discussion of the range of differences between institutional and everyday talk). Unlike everyday conversation, it has a pre-ordained, mutually agreed and specific purpose -- that is, in general terms, to improve the client's mental health -- and, like any institutional encounter between a practitioner and client, it entails an asymmetric conversational relationship between the participants (in this case, for example, one asks questions, the other tells their troubles, and so on). On the other hand, unlike many other institutions, psychotherapy does not always maintain "businesslike" emotional neutrality: it can resemble everyday conversation between friends, involving disclosures of personal experiences and emotional expression and response.

This personal and affective talk, however, is in many ways institutionally shaped: the talk is (mostly) of the client's, not the therapist's, personal experiences, and the interaction is very much informed by the psychotherapist's professional theories (cf. Parsons 1951: 461). Moreover, the epistemic relation between practitioner and client is specific to the theory and nature of psychotherapy: while the client may be granted primary access to his or her own experience, the therapist, drawing on his or her clinical knowledge, is entitled to propose that the client's experience is actually different than what the client thinks it is. This kind of epistemic "twist" is perhaps most evident in the psychoanalytic tradition - which was the first form of psychotherapy -- where the therapist's interpretations can refer to the client's unconscious, for example to unconscious resistance towards the therapy or the therapist (see e.g. Vehviläinen 2003). 
Since the relationship between the therapist and the client is realized through talk, psychotherapy is a fascinating research topic for linguistic and social scientific research that focuses on the practices of talk. Conversation Analysis (CA) is one of these strands of research, and in their review of conversation analysis of psychotherapy, Peräkylä et al. (2008: 16) build a bridge between the psychological and the interactional aspects of the psychotherapeutic process by suggesting that anything a therapist or a client does, is done and understood in the context of the other participant's previous turn(s) at talk. In responding to each other, the client and the therapist inevitably convey an understanding of the client's (and the therapist's) experience (as it has been expressed) and how one might relate to that experience. Because turns are tied together by adjacency, in responding to the prior action "the participants inevitably have to orient to and work with the understandings of the experience that they each bring about through their actions" (Peräkylä, et al., 2008: 16), and it is this interplay of understanding - regarding both the content of the talk and the relation to the co-participant -- that brings the therapeutic process forward (Peräkylä, et al., 2008: 16, Peräkylä 2012).

In what follows we will review how these actions have been described in interactional (mostly conversation analytical) research of psychotherapy. In separate sections of the body chapter we will survey research on the sequential actions that are carried out in therapy, separated into the therapists' offering of versions of the clients' experiences and then the clients' reactions; then consider the interactional trajectory of the session (and the series of sessions), and finally make some notes on emerging work on comparative studies of different forms of therapy before offering some comments about future directions. First, however, we will briefly review the history of linguistic and social scientific research of therapeutic conversation. 


\section{Pioneering research on therapeutic conversation}

As soon as the modern audio and video recording technologies started to develop, and the methods for the investigation of spoken interaction started to emerge, psychotherapy interaction became an object of social scientific and linguistic analysis. In fact, research on language and social interaction based on audio- and video recorded data started from research that focused on psychotherapy and psychiatric interviews. The pioneering projects involved some of the leading anthropologists, linguists, and psychiatrists of the time, such as Gregory Bateson and Frieda Fromm-Reichmann (for a fuller account of this history, see Kendon 1990: $15-21)$.

The first major milestone in this line of research was the analysis by Pittenger, Hockett and Danehy (1960), who described in detail an audio recording of the first five minutes of an initial psychiatric interview, paying particular attention to the implicit meanings conveyed by the lexical and prosodic choices of the participants. The explorative study offers a wealth of minute observations regarding a short segment of therapeutic interaction, without trying to make any generalizations about recurrent structures or practices in this interview, let alone in therapeutic interaction in general. The general findings that the authors do offer (pp. 228250) go beyond the realm of therapeutic interaction and have to do with the (then emergent) general theory and method of research on spoken interaction. For example, the authors conclude that utterances will always communicate something about their speakers and recipients and their immediate context of communication, alongside the more symbolic referential work that they do. 
Another major milestone in the social scientific and linguistic analysis of psychotherapeutic interaction is Labov and Fanshel's "Therapeutic Discourse: Psychotherapy as Conversation" in 1977. Labov and Fanshel characterize their work as "comprehensive discourse analysis", and their analysis indeed embraces various layers of organization of the verbal interaction, spanning phonological detail to overall "frames" of discourse. At the core of Labov and Fanshel's analysis are what they call speech acts (though these are different from the more familiar linguistic sense of the term from Austin and Searle): the often implicit, multilayered actions that are performed through utterances. They single out four basic types of actions meta-linguistic action, representation, request, and challenge, that the therapy is built from (Labov and Fanshel 1977: 60-65). In and through the examination of the matrix of these actions, they address themes that are pertinent in the professional understanding of psychotherapy, such as emotion and repression. Like "First five minutes", this study also offers suggestions concerning the general theory and method of interaction analysis (Labov and Fanshel 1977: 354-361). For both the study of conversation in general, and psychotherapy in particular, one influential distinction Labov and Fanshel introduced was between descriptions of a state of affairs and the kind of knowledge participants are taken to have of it. Thus, an "A-event" is biographical or experiential information to which the speaker, but not others, has privileged access; and a "B-event" is conversely a matter in another person's experience, to which the speaker has limited access.

A study by Scheflen (1973) also involved microanalysis of a filmed segment of family therapy, focussing especially on the coordination of participants' language, posture and gesture. Scheflen shows how the talk of the participants is coordinated with their body 
posture, producing nine basic positions such as "explaining", "passive protesting", “contending" and "defending" (see esp. p. 33). Likewise, Schelfen shows how the postures and postural changes of a participant are related to those of other participants.

Later Ferrara (1994) used discourse analytical methods similar to those of Labov and Fanshel. Unlike the early studies mentioned above, Ferrara does not focus her study to a single segment of therapy talk but uses a data base of 48 hours of therapeutic interaction in the production of which six therapists and ten clients were involved. Ferrara's study explores the linguistic features of a number of recurrent "discourse strategies" in psychotherapy: personal experience narration, dream narration, repetition of the other's talk, construction of metaphors, and joint production of utterances. Ferrara's (1994: 52-83) analysis of storytelling focusses on the different uses of retellings (telling once more the same or a similar story) in therapy. She makes a distinction between three types of retellings, involving (1) the same event but a different point, (2) different events but the same point, and (3) similar events and the same theme. In describing type 1 retellings, she for example observes increasing animation in the subsequent tellings. Through retellings of type 2 , the patient can display her understandings of recurrent patterns in her behavior, which is a central activity in psychotherapy. Type 3 retellings have much in common with type 2 , but in type 3 , the patient does not him/herself design the stories as ones that are linked, but instead, the therapist points out such connections. Ferrara's work on retellings resonates with more recent studies in conversation analysis exploring the continuity of themes over sessions (Voutilainen et al. 2011, Peräkylä 2011, Bercelli et al. 2013).

Conversation Analysis interest in psychotherapy started with its main founder, Harvey Sacks, in his early work on naturally occurring conversations. Sacks used, among other types of recordings, a set of audio-taped recordings from a group therapy session (see especially Sacks 
1992, vol.1: 268-80). In investigating these recordings, Sacks and his colleagues made a number of observations that generated further conversation analytic research of generic properties of interaction, but they do not involve an extensive effort to understand what is specific in psychotherapy as interaction. An illuminating discussion of the "omnirelevance" of the categories therapist and patient in such interactions (Sacks, 1992, vol 1: e.g. 315 and 462) is perhaps the closest that Sacks came to the investigation of institutionally specific properties of psychotherapy interaction.

Conversation analytic (CA) work on practices specific to psychotherapy began with a now widely cited paper by Davis (1986) on problem reformulation in psychotherapy. Since the late 1990s, the theme was taken up by other CA researchers, which eventually led to the current busy scene of research. In what follows, we will review some of the most recent research on psychotherapy interaction, mostly drawing upon conversation analytical research. First, we will discuss how psychotherapy is done by dint of certain types of conversational actions by the therapists and the clients. We will focus on two major themes: 1) therapists' actions in which the therapist communicates to the client what s/he has heard in the clients' talk and 2) clients' actions which convey resistance towards the therapists' understandings. Second, we will discuss how actions can follow each other in recurring ways, forming interactional trajectories that are in the service of a therapeutic agenda. Third, we will discuss recent developments in longitudinal and comparative studies of psychotherapy, and consider future directions for the study of therapeutic conversation. It is worth noting that although we may use unqualified statements about the use of various practices that we describe, the samples from which CA research has drawn its conclusions have typically been rather small. While different types of psychotherapy, such as psychoanalysis (e.g. Vehviläinen 2003, Peräkylä 2004), cognitive therapies (e.g. Antaki et al. 2005, Bercelli et al. 
2008, Voutilainen 2010), systemic (e.g. Bercelli et al. 2008) and couples therapies (e.g. Muntigl and Kwok 2010), narrative and solution focused therapies (McMartin 2008), and integrative therapy (Rae 2008, Pawelczyk 2011) have been studied the research on therapeutic conversation has only recently (as we shall see later in the chapter) started to compare the different varieties of psychotherapy (see Weiste and Peräkylä 2013, forthcoming); so some caution is needed in assessing the range and scope of the findings we report.

\section{Sequential actions in psychotherapy}

\subsection{Therapists' versions of the clients' talk}

In various ways, psychotherapists offer clients their versions and understandings of the clients' talk. Interactional vehicles for doing this include formulations, interpretations and a number of other actions.

Formulations have been perhaps the most extensively researched facet of psychotherapeutic interaction (e.g. Davis 1986, Antaki 2008, Antaki et al. 2005, Bercelli et al. 2008, Buttny 1996, Hutchby 2005; Madill et al. 2001; Peräkylä 2004; Vehviläinen 2003). As Antaki (2008)

points out, the term formulation lends itself to various usages. The by now classical definition arises from Heritage and Watson's (1979) study, according to which formulations are utterances in which the current speaker suggests a meaning of what another participant has said in the prior turn or turns (elaborating on the term coined by Garfinkel and Sacks 1970, who used the term more specifically to refer to a speaker's suggestion of what was going on in the conversation at the time). A formulation is inevitably selective: it foregrounds something in the prior talk, and leaves something else in the background. It thereby involves 
what Antaki (2008) calls local editing of the interlocutor's talk. It makes relevant confirmation or disconfirmation by the recipient (the party whose talk is being edited). Thus for example, a therapist might say, after a client's account of a troubling episode, "so you felt very upset by that" or "so there may be no way out", and similar expressions (we will turn to real examples below).

Therapists' formulations of clients' talk have been shown to be multipurpose devices in psychotherapy. Formulations can serve, for example, to establish the events or experiences that the client has spoken about as therapeutically relevant or therapeutically irrelevant, to intensify and underline emotional or conflictual issues, to prepare the ground for interpretation, to challenge the client's reasoning and to manage the agenda of the therapeutic session (Antaki 2008, Antaki et al. 2005, Hutchby 2005, Peräkylä 2004, Vehviläinen 2003, Weiste and Peräkylä 2013). Besides serving these kinds of "strategic" purposes, formulations are also a basic means to communicate to the client that the therapist listens and understands the client. Weiste and Peräkylä (2013: 299) suggest that highlighting formulations, which "recycle the client's descriptions and recognize therapeutically dense material", and rephrasing formulations, "which offer the therapist's version of the client's description and focus on subjective experiences", are among the practices of interaction through which so called common factors of psychotherapeutic work (factors that are not specific to any type of therapy, see e.g., Wampold, 2001) are realized. In Weiste and Peräkylä's comparative study on cognitive therapy and psychoanalysis, these types of formulations were found from both the types of therapy. In highlighting formulations the therapist remains closest to the client's descriptions, whereas in rephrasing formulations she or he transforms the client's description and adds some elements that were not originally in the client's turn. 
Extract 1 shows an example of a rephrasing formulation from cognitive psychotherapy. Here, the client $(\mathrm{C})$ is describing her feelings on a morning bus on her way to work.

Extract (1) (from Weiste and Peräkylä 2013: 306)

$1 \mathrm{C}$ : ei silloin ei, (.) halua-is näh-ä ketään ihmis-i-ä ja? NEG.3SG then NEG.3SG want-COND.3SG see-1INF no-one person-PL-PAR and on those days I don't, (.) want to see anyone and?

2 (3.0) $\circ \mathrm{ja}^{\circ}($.$) jos (.) jollain \quad \uparrow$ bussi-in tulo kestä-ä and if someone.ADE bus-ILL coming take.time-1INF (3.0) ${ }^{\circ}$ and ${ }^{\circ}$ (.) if (.) someone gets onto $\uparrow$ the bus a bit more slowly

$3 \mathrm{C}$ : vähän pitempä-än nii mä-hän,(.) miele-ssä-ni jo 〈hauku-n> ja? (0.5) öö a.little longer-ILL PRT 1SG-CLI mind-INE-1SG PRT criticize-1SG and then I, (.) in my mind I'm already <criticizing them> and? (0.5) erm

$4 \mathrm{~T}: \mathrm{mmm}$.

5 C: kaikke-e tommos-ta oeto? everything-PAR DEM2.ADJ-PAR PRT things like ${ }^{\circ}$ that ${ }^{\circ}$ ?

$6 \mathrm{~T}$ : eli sit siin o-n aika voimakas semmone ärsyyntyny so then DEM3.INE be-3SG quite strong DEM3.ADJ irritated so then there is a quite strong such an irritated

7 [ja agressiivinen-ki olo. and aggressive-CLI feeling [and even aggressive feeling.

$8 \mathrm{C}$ : [joo: no siin $\quad$ hirveen <个herkä-ssä> ainaki \#just ärsyynty-mä-än yes PRT DEM3.INE very easy-INE at.least PRT get.irritated-3INF-ILL [yeah: very < $\uparrow$ easily> one gets at least \#irritated

9 > silleen niinku (.) rupe-e ärsyttä-ä<\# .hhh ohirveen herkästi॰ DEM3.MAN PRT begin-1INF irritate-3INF.ILL very easily

$>$ like that like (.) it begins to irritate <\#.hhh ${ }^{\circ}$ so easily ${ }^{\circ}$.

10 (2.5) ॰että ärtynyt olo? PRT irritated feeling

(2.5) 'so the feeling is one of being irritated?

11 T: M-hm. 
$13 \mathrm{~T}$ : Mut sä et pidä to-ta sitte. (1.0).hh semmose-na joka but 2SG NEG.2SG regard DEM2-PAR then DEM3.ADJ-ESS that But you don't think of that as. (1.0). hh something that

14 vo-is ol-la (.) aika yleistä-ki. .hehh can-COND.3SG be-1INF quite common-CLI might be (.) quite common. .hehh

The formulation in lines 6-7 is a response to the client's detailed description of the repetitive events on a morning bus. In the analysis of the extract, Weiste and Peräkylä (2013: 307) point out that in the formulation the therapist renames the core feelings experienced by the client, using common psychological vocabulary (the words irritated and aggressive feelings were not used by the client), and takes the focus away from the external events in the client's narration. The therapist thus displays understanding and directs the client's attention to her experience, making relevant further work with the experience (lines 8-14).

While a formulation suggests a meaning of what the patient has said in the prior turn or turns, an interpretation does more: it conveys the therapist's own view about the patient's mind and / or circumstances. Formulations can prepare ground for interpretations (Vehviläinen 2003, Peräkylä 2004), but there are also specific utterances, the main task of which is openly to convey to the patient the therapist's views. These utterances suggest that there is some additional meaning in what the patient has been talking about—-this meaning having to do with, for example, linkages between different spheres of experience (such as childhood and present) or relations between manifest and non-manifest experiences (such as manifest anxiety and non-manifest beliefs about self and others). In an open and explicit way, these utterances invite the patient to orient to and work with the new understandings that they propose. Vehviläinen (e.g. 2003) and Peräkylä (e.g. 2004) have called them simply interpretations (thus adopting the vocabulary of psychoanalytic clinical theory; see Greenson 
1967), while Bercelli, Rossano and Viaro (2008) use the term reinterpretative statement to refer to basically similar utterances. Below, we adopt the more simple term (interpretation), also when referring to the work of Bercelli and colleagues.

The difference between formulations and interpretations has been clarified by Bercelli, Rossano and Viaro (2008). They understand formulations along the lines suggested above, as utterances which, while proposing further significance of what the patient has said, frame what they propose "as something that was implicitly meant by the client" (p. 46). An interpretation, on the other hand, presents the analysis "as something that, though grounded in what the client has said, is caught and expressed from the therapist's own perspectivetherefore something possibly different, and ostensibly so, from what the client meant" (p. 47). Thus, the distinction made brings to the foreground the basic difference in the production format of the two therapeutic interventions: in formulation, the principal— "the party whose position the words attest" (Goffman, 1981b: 226)—of the therapist's utterance is, at least nominally, the client and in interpretation, it is the therapist. Thus, in delivering an interpretation while speaking about the patient's mind and circumstances, the therapist still uses his or her own 'voice' in full strength.

Bercelli et al. (2008: 49) point out that the linkage of interpretations to the therapist's own reasoning is often achieved by the use of epistemic markers and perspective markers, such as I think, in a sense or perhaps. Contrary to formulations, interpretations do not claim to maintain the sense and gist of what patients said. Therapists put forward their own perspective by offering versions of patients' events possibly divergent from those previously provided by patients (cf. also conclusions in Voutilainen et al. 2011). An example of an interpretation is shown below in the following section on clients' resistance. 
Besides formulations that are framed to display understanding of the client's words, and interpretations that are framed to present the therapist's perspective, research has also described therapist's actions where the client's and the therapist's "voices" (perspectives to the client's experience) seem to be converging (Vehviläinen 2003, Vehviläinen et al. 2008, Peräkylä 2008, Voutilainen et al. 2010, Pawelczyk 2011: 189-195, Weiste and Voutilainen, in prep.). In utterances that are syntactically fitted to the client's earlier talk, such as extension (Vehviläinen 2003, see lines 69-70 in the extract 2 below for an example), and lexical substitution (Rae 2008), the therapists continue or modify the client's description in ways that do not mark whether they are formulating ("you mean") or interpreting ("I think"), but rather seem to convey that the therapist rather, as it were, speaks "from within" the client's experience. One recurrent location to these kinds of utterances is an empathetic response to the client's affective talk. Voutilainen, Peräkylä and Ruusuvuori (2010) describe recognition of experience, in which the therapist adds details to the client's description of her experience (in the form of extension or direct statement) and so conveys that she understands the client's experience and sees it as real and valid. Peräkylä (2008) discusses cases where the psychoanalyst's extensions created specific kind of moments of mutual understanding that in clinical terms might be referred to as "moments of meeting" (Stern 2004). On the other hand, extensions of the client's talk and direct statements can also convey interpretive or confrontative content. Such confrontation can be in subtle ways embedded in empathy or agreement (see Rae 2008, Voutilainen et al. 2010, Peräkylä 2008, 2011), or have a more directly challenging tone (Vehviläinen 2008, Weiste and Voutilainen, in prep.).

\subsection{Clients' resistance to therapists' moves}

As Vehviläinen (2008: 120) points out, some mismatch between the professionals' and the clients' actions is common in perhaps all institutional settings: "professionals encounter 
moments where patients resist their actions and institutional agendas." In psychotherapy, resistance is particularly important and possibly significant. Client resistance is not only an obstacle (i.e. something that needs to be sorted out in order for the therapy to take place), but rather, part and parcel of the very activity of doing therapy (see Vehviläinen 2008).

Practitioners of course have theories about resistance and practical ways of handling it, but where CA can make a distinctive contribution is in showing the actual details of how resistance is offered by the client and dealt with by the therapist, at the level of the internal design of turns and at the level of their sequential organisation. CA research on psychotherapy has located resistance for example in clients' claims of not knowing (Hutchby 2002, Falk 2013) or not remembering (Muntigl and Kwok 2010). MacMartin (2008) shows how clients of solution-focused therapies resist the therapist's "optimistic questions". These optimistic questions are presuppositional questions that are "built so as to prefer answers from [clients] that affirm ...their agency, competence, resilience, abilities, achievements, or some combination thereof'(MacMartin, 2008: 82). However, in spite of the presuppositions embodied in the questions, Mac Martin shows that the patients recurrently do not, in their answers, view themselves as competent, resilient and able. The clients' ways of resisting the optimistic questions involve downgrading, refocusing, joking and sarcasm and even complaining about the question (McMartin 2008).

Similar to the therapist's interpretative and confrontative moves, client's resistance can also be discreet and embedded in agreement. In discussion of client's responses to interpretations in psychoanalysis, Peräkylä (2005) shows how clients, in their responses to interpretations, can select something from the therapist's interpretation to take up and elaborate on, and leave aside something else -- perhaps something that is more difficult to handle. Example 2 below shows a therapist's interpretation and a client's response which embodies this kind of a subtle 
resistance. In the extract, the therapist delivers an interpretation from line 16 onwards. Prior to the interpretation, the client (a middle aged man) talks about his disappointment in his mother for not having encouraged him as cross-country skier, when he was in his early teens. In the interpretation, the therapist proposes that the client has displaced his disappointment from father to mother, and that the target of the 'original' disappointment is the father who was not available for him in his childhood ${ }^{1}$.

Extract (2)

$1 \mathrm{P}: \mathrm{Ja}$ varsinkin se hiihto ol-i se mu-n, and especially DEM3.SG skiing be-PST.3SG DEM3.SG 1SG-GEN And especially skiing was my,

$3 \mathrm{C}:$ mu-n laji. 1SG-GEN sport my kind of sport.

$5 \mathrm{C}$ :. mthh $>$ Mut et siin $\quad(>$ ol-i< $) \quad$ niinko äidi-llä ol-i but PRT DEM3.INE be-PST.3SG PRT mother-ADE be-PST.3SG .mthh $>$ But there $(>$ was $<)$ my mother sort of had

6 jotenkin< nihkee |suhtautuminen sii-hen koko somehow sticky attitude DEM3-ILL whole somehow< a negative |attitude to that whole

7 homma-an että se suorastaan vähän niinku estel-i. business-ILL PRT DEM3.SG even a.little PRT try.to.stop-PST.3SG business so that she even tried to stop me.

$8 \quad(7.2)$

\footnotetext{
${ }^{1}$ In lines 16, 34, and 42, the therapist produces the kind of epistemic and perspective marking that Bercelli, Rossano and Viaro (2008) suggest is distinctive of psychotherapeutic interpretations: "Syvemmällä tasollahan"। On a deeper level (line 16) frames what the therapist says as involving a new perspective vis-à-vis the earlier talk; "Mä luulen" / I think (line 33) marks the proposal as arising from the therapist's own reasoning, and "Ja se ilmenee tällä tavalla että" / It shows in this way that (line 42) indicates the therapist's reasoning from which the proposal arises.
} 
$9 \mathrm{C}$ : > Jotenki mu-lla o-n niinku semmonen< (0.6) tunne somehow 1SG-ADE be-3SG PRT DEM3.ADJ feeling $>$ Somehow I have the $<(0.6)$ feeling that

10 (.) ol-i sillon ja nyt (.) nyt vielä-kin että be-PST.3SG then and now now still-CLI COMP (.) had it then and still (.) still have it

11 .hhh (0.2) että las-ta pitäs päinvastoin COMP child-PAR should instead .hhh (0.2) ${ }^{\circ}$ that rather than doing that a child

12 kannusta-a niinkun tommose-en ${ }^{\circ}$ (homma-an $)^{\circ}$. encourage-1INF PRT DEM2.ADJ-ILL business-ILL should be encouraged in that kind of ${ }^{\circ}$ (activity) ${ }^{\circ}$.

$13 \quad(8.5)$

14 T: Joo:o, Yeah:

$15 \quad(4.2)$

16 T: hh Syvemmä-llä taso-lla-han se merkitse-e si-tä deeper-ADE level-ADE-CLI DEM3.SG mean-3SG DEM3.SG-PAR .hh On a deeper level it means you know

17 että (0.6) mt että äiti ei, COMP COMP mother NEG.3SG

that (0.6) tch that the mother ${ }^{\wedge}$ wasn't

$18 \quad(2.0)$

$19 \mathrm{~T}: \wedge^{\wedge}$ ol-lu isä be-PPC father .the father.

20

((13 lines omitted $))$

33 .hhh >ja koska se tämmönen<=\#y::\# > Mä luule-n and because DEM3.SG DEM1.ADJ 1SG think-1SG .hhh > and because this kind $<=\#$ er::\# >I think

34 et su-n o-n< v:aikea oikeestaan (1.2) COMP 2SG-GEN be-3SG difficult actually 
that it's actually< diff:icult for you (1.2)

35 myöntä-ä si-tä että että y’ (.)

admit-1INF DEM3.SG-PAR COMP COMP

to admit that that eh (.)

36 is\#ä:\# isä puuttu sinu- $1^{\circ} \mathrm{ta}^{\circ}$.

father father be.missing.PST.3SG 2SG-ABL

you didn't didn't have a $\mathrm{fa}^{\circ}$ ther ${ }^{\circ}$.

$37 \quad(1.2)$

38 T: Si-llä tava-lla et se ol-i vähän niinku äidi-n vika, DEM3.SG-ADE way-ADE COMP DEM3.SG be-PST.3SG a.little PRT mother-GEN fault So that it was as it were the mother's fault,

$39(1.3)$

$40 \mathrm{~T}$ : mt lettä isä puuttu.

COMP father be.missing.PST.3SG

tch |that the father wasn't there.

$41 \quad(0.7)$

42 T: hh Ja se ilmene-e tä-llä tava-lla että

and DEM3.SG show-3SG DEM1.SG-ADE way-ADE COMP .hh And it shows in this way that

43 .hhh (0.2) \#ä:\# sie kaipaa-t nii-tä ominaisuuks-i-a

2SG miss-2SG DEM3.PL-PAR characteristic- PL-PAR

.hhh (0.2) \#er:\# you miss the characteristics

44 (0.8) joita <isä-ssä ol-isi ol-lut>

that.PL father-INE be-COND.3SG be-PPC

(0.8) that <the father would have had>

$45 \quad(2.2)$

$46 \mathrm{~T}$ : Ja (.) oo-t tyytymätön äiti-in nyt and be-2sG dissatisfied mother-ILL now And (.) you are dissatisfied now with mother

47 sii-tä (0.7) mt että >äidi-llä ei DEM3.SG-PAR COMP mother-ADE NEG.3SG for the fact (0.7) tch that the $>$ mother didn't

48 ol-lu< nii-tä $\quad$ ominai $^{\circ}$ suuks-i-a ${ }^{\circ}$. be-PPC DEM3.PL-PAR characteristic-PL-PAR |have $<$ those character ${ }^{\circ}$ istics $^{\circ}$. 
50 T: Että äiti ei ol-lu isä. COMP mother NEG.3SG be-PPC father That the mother wasn't the father.

$51(3.5)$

52 T: \#Isä-n::\# (1.0) tehtävä-nä-h'n (.) tavallisesti father-GEN duty-ESS-CLI normally \#It's the fa:ther's (1.0) duty (.) normally

53 o-n: (1.0) \#(juu:r) i::\#nnosta-a (0.5) poika-a u be-3SG encourage-1INF son-PAR is (1.0) \#( ) to e\#ncourage (0.5) the son in $o$ -

54 ulkoilu-un ja urhei ${ }^{\circ} l u-u n^{\circ}$. outdoor.activities-ILL and sports-ILL outdoor activities and ${ }^{\circ}$ sports ${ }^{\circ}$.

$55 \quad(6.0)$

56 Th: mt Metsä-lle ja, forest-ALL and tch In hunting expeditions and,

$57 \quad(1.5)$

$58 \mathrm{~T}$ : urheilukent-i-lle ja niin edel ${ }^{\circ}$ leen ${ }^{\circ}$. athletic.field-PL-ALL and PRT onwards in athletic activities and so ${ }^{\circ} n^{\circ}$.

$59 \quad(18.5)$

$60 \mathrm{P}: \quad$. mthhhhff hhhmthh (1.0) mt hhhh .mthhhhff hhhmthh (1.0) tch hhhh

$61 \quad(6.2)$

62 C: .mthh Nii::, (.) Tot-ta-han se o-n (.) o-n tietysti, PRT truth-PAR-CLI DEM3.SG be-3SG be-3SG of.course .mthh Yeah:., (.) It is true (.) true of course,

63 =Isä-n-hän siellä ladu-n varrella

father-GEN-CLI there skiing.track-GEN along

$=$ It is the father who > should have been< there

$64>$ >-is pitä-ny< ol-la. 
be-COND.3SG should-PPC be-1INF

by the skiing track.

$65 \quad(0.8)$

66 C: $\quad$ Hihku-ma-ssa.=>Ei-kö niin<. whoop-3INF-INE NEG-Q PRT

Whooping. $=>$ shouldn't he $<$.

67 T: Niin.

PRT

Yeah.

$68 \quad(10.0)$

69 T: .hh Ja urheiluseura-n\#::\# johtokunna-ssa and sports.club-GEN board-INE .hh And on the board of the sports club

70 (1.0) tuke-ma-ssa nuor-te-n työ-tä. support-3INF-INE youngster-PL-GEN work-PAR

(1.0) supporting the youngsters' work.

$72 \mathrm{C}: \quad{ }^{\circ} \mathrm{Nii}:^{\circ}$,

PRT

${ }^{\circ}$ Yeah: ${ }^{\circ}$,

$73 \quad(35.0)$

Peräkylä (2005) and Bercelli et al. (2008) have made converging observations regarding the ways in which therapists design interpretative utterances so as elicit more than a minimal response from the client. A key technique involves, in the face of minimal or no response from the client, the therapist adding increments to his/her own interpretations, thus pursuing a more elaborate response. In Extract 2, the interpretation is hearably complete, for example, in lines 36, 40, 44, 48, 50 and 54. At these points, a response from the client would be relevant. In the absence of any response from the client, the therapist continues, thus creating new opportunities for the client to respond. 
Recurrently, clients respond to interpretations with what Peräkylä (2005) calls elaboration and Bercelli et al. (2008) call extended agreement: an utterance through which the client shows his or her agreement and understanding of the interpretation by offering evidence for the interpretation (Bercelli et al. 2008: 56-7), or illustrating or explaining what was proposed in the interpretation (Peräkylä 2005: 165). In Extract 2, the client's response to interpretation occurs in lines 62-4 (simplified): the client first displays his agreement in compact form ("Nii, Tottahan se on tietysti" / Yeah it is true of course) and thereafter moves on to illustrate what was said in the interpretation ("Isänhän siellä ladun varrella ois pitäny olla" / It is the father who should have been there by the skiing track). Through this extended agreement (elaboration), the client documents his understanding of the interpretation.

Peräkylä (2005) has suggested that besides (overt) agreement, the client's elaboration can, at the same time, involve also indirect resistance to the interpretation. In the extract 2 above, if we consider the topical development of the interpretation through the increments, we see that the therapist eventually offers an account of a father's conventional duties as evidence for his initial statement regarding the displacement of disappointment from father to mother. By focusing his elaboration on this final, incremental part of the interpretation - that was produced in face of lacking earlier patient of response -- the client displays (partial) agreement with the interpretation (at least in terms of conventional duties of a father) but avoids directly elaborating the material offered in the earlier parts of the interpretation (the displacement of the disappointment from mother to father). . In a similar vein, after the formulation shown in the extract 1 above (from line 8 onwards), the client agrees with the therapist's rephrased version of her experience and, as was made relevant in the formulation, focuses on her own subjective experience (rather than the external events). However, while adopting one of the therapist's terms (irritated, see lines 8, 9, and 10), she focuses away from 
the other proposed feeling, aggression (Weiste and Peräkylä 2013: 307). Longitudinal studies on these same data show that these themes in question (disappointment at father, relating to aggression) were problematic to these particular clients and they are recurrently worked with in their therapies (Peräkylä 2011, Voutilainen et al. 2011). It is important to note that in both the extracts above, in their subsequent turns after the client's responses, the therapists do not pursue direct talk of the content that was resisted by the clients. We could argue that this kind of partial agreement and partial resistance, and the therapist's sensitivity to it, is perhaps the very means of working with the emotionally problematic content in psychotherapy (Vehviläinen 2008, Peräkylä 2011, Voutilainen et al., 2011).

We can now summarize what we have suggested, in this and the preceding section, regarding the therapist's versions of the clients talk, and the patient's resistance. The actions that we described -- the therapist's formulations, interpretations and extensions, and the client's agreement or resistance (or combination of agreement and resistance) to them -- are interactional vehicles for the "interplay of understanding" and the momentary relationship between the therapist and the client (Peräkylä et al. 2008: 16, Peräkylä 2012). It is in these actions that the clients' problematic experiences get recognized and modified, and through them, the participants' understandings regarding these experiences meet, get transformed, or depart. Adjacent utterances are at the heart of these actions, and the psychological processes that they represent. Relations between adjacent utterances are the basic unit of analysis also in the studies that we will focus on the next section. However, in what follows we will there discuss the longer courses of action, or interactional trajectories, that the adjacent utterances are part of. 


\section{Interactional trajectories}

Many studies have shown that therapists' local responses, such as formulations (e.g. Davis 1986, Antaki et al. 2005) to the clients' utterances, and their responses to the clients' emotional descriptions (Voutilainen 2012) modify clients' words. They direct the client's talk towards what is relevant in preparing grounds for the therapist's later statements. In their study on psychoanalysis, Vehviläinen (2003) and Peräkylä (2004) describe how the analysts, in responding to the clients, can build grounds for later interpretations. In this interpretative trajectory the analyst, through modifications of the client's descriptions in formulations, confrontations and extensions, creates a puzzle that eventually gets solved in the actual interpretation. In other words, the interpretation explains a case that has been collaboratively built in earlier, less manifestly interpreting responses by the therapist. In this way, the earlier responses do preparatory work to make the interpretations more plausible and less far-fetched from the point of view of the clients. This kind of preparatory work also allows the therapists to utter interpretations that might in their local context seem rather strong claims as B-event statements (Vehviläinen 2003, Peräkylä 2004).

On the basis of their study on cognitive and systemic therapies, Bercelli et al. (2013) suggest that in so-called directive psychotherapies (in contrast to psychoanalysis and client-centered approaches) the progression from client's tellings to the therapist's versions of the clients' experience is a more structured path that proceeds from enquiry sequences to elaboration sequences. In enquiry sequences, through questions and formulations, the therapists "elicit and co-construct the clients' tellings about their events" (ibid, p. 118). In elaboration, the therapists "offer their versions of what has been told by the clients in enquiry sequences", and

make relevant an elaboration by the client (ibid, p. 118). The elaboration sequences are based 
on the enquiry sequences, and thus come after them. These sequences are generally started by therapists, who thus direct the unfolding of the talk (Bercelli et al. 2013:122).

In a study on cognitive therapy and psychoanalysis, Weiste and Peräkylä (forthcoming) show that interactional trajectories can be launched also in subtle, nonverbal means. Weiste and Peräkylä describe two alternative interactional trajectories (following the client's talk about affective experiences) that are found from both cognitive therapy and psychoanalysis: one in which the therapists remain focused on the feeling that the client has expressed, and validate that feeling; and another in which the therapists change the perspective so that rather than attending to the client's description of emotion as such, the therapist evaluates or even challenges what the client has said. Such a trajectory is launched by a formulation that initially responds to the client's description of an emotional experience. Importantly, the difference between the two trajectories is not evident in the lexical design of the therapist's initial formulation: in both trajectories, the therapist's formulation names the client's emotion in common psychological terms. However, through the analysis of the prosody of these initial formulations, Weiste and Peräkylä show that the prosodic features of the therapist's formulations incorporate the choice of trajectory (validating / challenging) in an anticipatory way. Lexically, the trajectory - be it validating or challenging - is manifested in the therapist's third position utterance after the client's response to the formulation. Formulations leading up to the validating trajectory involved prosodic continuity: "the therapists' intonation continued the intonation or rhythm of the client's preceding turn, and the therapist also lowered his or her voice, spoke quietly and used level intonation [...]. Formulations leading up to the challenging trajectory were characterized by prosodic disjuncture: there was a discontinuation in the intonation and rhythm between the client's and the therapist's turns, the pitch span in the therapist's turn was wider and the therapist spoke in 
a higher and louder voice than the client in the prior talk" (ibid, xxx). Weiste and Peräkylä point out that the participants themselves treat formulations with continuous prosody as conveying emotional empathy: the clients by allowing themselves to "be with the feeling" after such formulations, and the therapists by explicit validating utterances in the third position. In contrast, when the expression of understanding is conveyed only verbally (without prosodic continuity), participants do not show this kind of orientation to emotion. (Weiste and Peräkylä, forthcoming: XXX).

\section{Longitudinal change in interaction}

So far, we have presented studies that investigate "within session" interactions in psychotherapy: actions and trajectories that take place during single psychotherapeutic sessions. Recently, however, the time span of the phenomena of interest in interactional studies of psychotherapy has got wider. Researchers have started to investigate longitudinal, "across sessions" interactional processes. This has made it possible to address more directly also the question of therapeutic change (Voutilainen et al. 2011, Peräkylä 2011, 2012, Bercelli et al. 2013, Muntigl 2013). Inspiration for this new line of research has been drawn from studies on learning in interaction (e.g. Mondada and Pekarek Doehler 2004, Melander and Sahlström 2009).

In a study on cognitive therapy Voutilainen, Peräkylä and Ruusuvuori (2011) suggest that therapeutic change can be documented from a change in a particular type of sequence that recurs across sessions. In the case study from cognitive therapy, the client's responses to the therapist's conclusions -- in which the therapist challenges the client's tendency to transform 
her anger to self-blame -- were recast over time: from rejection through ambivalence to agreement.

Peräkylä $(2011,2012)$ suggests that therapeutic change processes can be located through following thematic threads (Schegloff 2007) that precede and follow a particular intervention, in this case a psychoanalytic interpretation. Peräkylä's study on psychoanalytic data shows how the therapist's third position utterances (coming after the interpretation and the patient's response, such as lines 69-70 in the example 2) modify in subtle ways the client's description of his/her experience. These modifications are not necessarily taken up by the client in their subsequent turns but may still have their repercussions in later sessions.

Furthermore, Bercelli, Rossano and Viaro's. (2013) study on cognitive and systemic therapies shows that the recurrent course of action found in their data, proceeding from enquiry to elaboration (see above) -- and possibly to displays of change by the client after -- does not need to take place in a single session but it can continue over several sessions. Explicit or embedded tying practices show how the participants resume past talk and link distant sequences into unitary courses of action.

Another perspective to longitudinal processes was taken by Muntigl (2013) whose study on recurring client's resistance in couples therapy shows that besides locating a positive change, longitudinal studies can also focus on the interactional history of escalating problematic interactions.

The emergent longitudinal CA studies encourage further examination of the therapeutic process beyond the local consequences of actions (Vehviläinen et al. 2008). They suggest that CA of psychotherapy may not only document that a therapeutic change has taken place but 
also locate specific moments in time (such as third position utterances in Peräkylä 2011) where the change seems to be emerging (see also Lepper and Mergenthaler 2008).

\section{Comparative studies}

The study of institutional interaction is inherently comparative, as it aims at explicating the variation of conversational actions across settings, in order to show how actions are modified for institutional purposes. Recently, interactional research on psychotherapy has also begun to take a more explicitly comparative perspective to therapeutic conversation by comparing interactional practices in different types of psychotherapy.

In a case study comparing demonstration sessions by founders of two therapy types -- James Burgental's experiential therapy and Aaron Beck's cognitive therapy -- Kondratyuk and Peräkylä (2011) describe a practice of guiding a client into immediacy that was specific to the experiential approach. This practice, repetitively used by the therapist (Burgental), involved shift in time perspective: the therapist's utterance followed the client's talk about an issue that was viewed from past or present-in-general perspective, and requested the client to view it from the perspective of immediacy. Comparison to cognitive therapy revealed that in Beck's session similar kinds of features of turn design -- shift to present tense and reference to "right now" - had a different function. By investigating sequential consequences of the therapist's interventions, Kondratyuk and Peräkylä show that in cognitive therapy, the shift to present did not guide the conversation into "the immediate moment of living, but to an unspecified present outside and around the therapeutic encounter" (p. 325), and to viewing connections between the past and present. Kondratyuk and Peräkylä (p. 327) locate the difference between immediacy (in Burgental's approach) and general present (in Beck's approach) also 
to lexical choice: to Burgental's use of ambiguous verbs and word combinations for describing the inner processes to be launched in a client, as well as often neutral ' it'” or "that" subject (such as" "how it's in you right now" "what does that trigger inside of you" what does it bring up right now for you'), and in contrast to that, to Beck's use of concrete descriptions and person references.

Weiste and Peräkylä (2013, forthcoming) compare two prominent forms of psychotherapy: psychoanalysis and cognitive psychotherapy. According to Weiste and Peräkylä (2013: 301302), these two types of therapy are good cases for comparison because they are widespread practices, and they are based on well-articulated clinical theories that are in many ways different, and in some points even contrastive. In its classical form, psychoanalysis aims at helping the clients to become aware of unconscious mental phenomena (e.g., Greenson 1967: 26), whereas classical cognitive psychotherapy is more focused on the present time problems and focuses on investigating and modifying the client's dysfunctional cognitions and beliefs (Beck et al. 1979: 6-7, Weiste and Peräkylä 2013: 302 ). Weiste and Peräkylä’s (2013) comparative study on formulations in these two types of therapy shows that these theoretical positions indeed resonate with the actual interactional practices: it was found that relocating formulations that "propose that the experiences in the client's narratives are connected to experiences at other times or places" appeared only in psychoanalysis, whereas exaggerating formulations, that "recast the client's talk as something that is apparently implausible, appeared only in cognitive psychotherapy" (ibid: 299). Weiste and Peräkylä point out that the contrast between relocating and exaggerating formulations suggests that interactional differences still exist between cognitive psychotherapy and psychoanalysis. 
On the other hand, as were discussed above, Weiste and Peräkylä (2013, forthcoming) report also practices that were common to the both types of therapy: highlighting and rephrasing formulations and prosodic features anticipating different trajectories. They suggest that these practices might be part of what constitutes so called common factors that relate to the working alliance between the client and the therapist, and are not restricted to any specific type of therapy. Weiste and Peräkylä's comparative study thus suggests that the interactional study of psychotherapy can show which practices are common to various forms of therapies, and which are specific to certain approaches.

Specific features of psychotherapeutic interaction can be clarified also through comparison to other types of encounters. Ruusuvuori and Voutilainen (2009) compared affiliation with troubles-teller in three kinds of settings: everyday talk, medical encounters and cognitive psychotherapy. They show that while in everyday conversation affiliation is the default response to trebles-telling, in institutional encounters affiliative orientation to the problematic experience as such is subordinated to (in medical encounters) or intertwined with (in psychotherapy) the institutional "business" of working with the problematic experience. The comparison of medical encounters and psychotherapy reveal how the institutionally specific relation between the professionals and the clients is realized in interaction. In medical encounters, affiliation with the patient's experience is treated as a side issue, and (in the Finnish data) designed using the so-called zero-person reference where the actual person reference is missing but the verb is in third person singular (on zero-person construction, see Laitinen 1995). In contrast, in cognitive psychotherapy, the therapist's affiliation with the client's experience constitutes a key part of the psychotherapeutic work with that experience, and it is often made with a direct reference in the second person singular, for example by stating that "You would need it [acceptance from mother] so much" (Ruusuvuori and 
Voutilainen 2009: 223-224). In psychotherapy, thus, the professional can make as it were more direct claims about the client's inner experience than the professionals of somatic medicine.

\section{Future directions}

Interaction research, be it linguistic or social scientific, usually focuses on what is manifest in interaction: utterances, actions, and projects that involve voice, words, body positions and movements. However, in psychotherapy the interactional surface often involves an orientation to the inner world of the client: to implicit meanings and investigation of the client's unsaid thoughts and feelings, as well as orientation towards change in the inner experience of the client. In this respect, interactional research of psychotherapy has also addressed the mental worlds of the participants: for example the emotional experience and the unconscious resistance, as far as they appear in the shared, intersubjective realm. As we pointed out in the beginning of the chapter, the interactional and internal processes can be seen as intertwined in the "interplay of understanding" that evolves in the therapeutic interaction (Peräkylä et al. 2008: 16). We believe that one further direction that the interactional research on psychotherapy can take is to "cross the border" between the social and mental phenomena, and empirically investigate the relation between interactional and internal processes: for example, how the emotion or empathy that is displayed in the interaction is reflected in the psychophysiological emotion process of the participants. For investigating these kinds of questions, combination of different methods and research traditions is needed. For example, combination of a quantitative application of conversation analysis, and psychophysiological measurement, can yield new insight about the relation 
between conversational actions and changes in autonomic nervous system activation (Voutilainen et al. 2013).

A general theme for future research on therapeutic conversation is, in line with the recent work of Muntigl and Horvath (2013), to further investigate the constitution of the therapeutic relationship, how it is created, maintained and negotiated. Further research on interactional management of emotion and epistemic organization is needed, to show how the problematic experiences are shared and worked with through talk. An emerging theme in the study of therapeutic conversation is also the organization of interactional acts other than full verbal utterances: facial expression, gesture, prosody and minimal verbal responses (e.g. Fitzgerald and Leudar 2010, Pawelczyk 2011: 79-95, Hepburn and Potter 2012, Weiste and Peräkylä, forthcoming, Muntigl 2012).

Future research will probably involve both the further expansion of the longitudinal and comparative studies, and continuous basic research on the sequential organization of action in psychotherapy: what kinds of actions there exist in psychotherapy, how they are formatted, what psychotherapeutic functions they carry and how they get responded by the coparticipant. The picture that the interactional research of psychotherapy draws about therapeutic conversation probably will remain complex and less straightforward than the picture that research has yielded for example about the medical consultation. The organization of psychotherapeutic talk is so multi-faceted (involving overt actions as well as covert projects and dispositions) and variable by approach, clinician and client (Kondratuyk and Peräkylä 2011, Peräkylä 2012) that a straightforward global model of psychotherapeutic interaction is not to be expected. However, we expect further findings - and some accumulation of them -- on sequential relations of therapists' and clients' actions that will teach us more about the "real world" ways in which psychotherapy is done through talk. 


\section{References:}

Antaki, Charles. 2008. "Formulations in psychotherapy.” In Conversation Analysis and Psychotherapy ed. by Anssi Peräkylä, Charles Antaki, Sanna Vehviläinen and Ivan Leudar, 26-42. Cambridge: Cambridge University Press.

Antaki, Charles, Rebecca Barnes and Ivan Leudar. 2005. "Diagnostic formulations in psychotherapy”. Discourse Studies 7: 627-647.

Bercelli, Fabrizio, Federico Rossano and Maurizio Viaro. 2008. "Clients' responses to therapists' re-interpretations." In Conversation Analysis and Psychotherapy ed. by Anssi Peräkylä, Charles Antaki, Sanna Vehviläinen and Ivan Leudar, 43-62. Cambridge: Cambridge University Press.

Bercelli, Fabrizio, Federico Rossano and Maurizio Viaro. 2013. "Supra-session courses of action in psychotherapy." Journal of Pragmatics 57: 118-137.

Buttny, Richard. 1996. "Client's and therapist's joint construction of the client's problems." Research on Language and Social Interaction, 29 (2): 125-153.

Davis, Kathy (1986). The process of problem (re)formulation in psychotherapy. Sociology of Health and Illness 8: 44-74. 
Drew, Paul and John Heritage. 1992. Analyzing talk at work: an introduction. In Talk at work: interaction in institutional settings ed. by Paul Drew and John Heritage, 3-65. Cambridge: Cambridge University Press.

Falk, Hanna. 2013. Discussing Anorexia. A conversation analytical study on treatment discussions between anorectic patients and professionals. Publications of the Department of Social Research 2013:11, Sociology, University of Helsinki.

Ferrara, Kathleen W. 1994. Therapeutic Ways with Words. Oxford: Oxford University Press.

Fitzgerald Pamela and Ivan Leudar. 2010. ”On active listening in person-centred, solutionfocused psychotherapy." Journal of Pragmatics 42, 3188-3198.

Garfinkel, Harold and Harvey Sacks. 1970. "On formal structures of practical actions.” In Theoretical Sociology, ed. by John C. McKinney and Edward A. Tiryakian, 337-366. New York: Appleton-Century-Crofts.

Greenson, Ralph R. 1967. The Technique and Practice of Psychoanalysis. Madison, CT: International Universities Press.

Hepburn, Alexa and Jonathan Potter. 2012. "Crying and crying responses. In Emotion and Interaction ed. by Anssi Peräkylä and Marja-Leena Sorjonen, 195-211. Oxford: Oxford University Press. 
Heritage, John and Steven Clayman. 2010. Talk-in-Action: Identities, Interaction and Institutions. Boston: Wiley-Blackwell.

Heritage, John and Rod Watson. 1979. "Formulations as Conversational Objects". In Everyday Language ed. by George Psathas, 123-162. New York: Irvington Press.

Hutchby, Ian. 2005. “Active Listening”: Formulations and the Elicitation of Feelings-Talk in Child Counselling”. Research on Language and Social Interaction, 38: 303-329.

Hutchby, Ian. 2002. "Resisting the incitement to talk in child counselling: Aspects of the utterance “I don't know”. Discourse Studies, 4: 147-168.

Kendon, Adam. 1990. Conducting Interaction: Patterns of Behavior in Focused Encounters. Cambridge: Cambridge University Press.

Kondratyuk, Nataliya and Anssi Peräkylä. 2011. "Therapeutic work with the present moment: A conversation analytical study of guidance into immediacy." Psychotherapy Research 21(3): $316-330$.

Labov, William and David Fanshel. 1977. Therapeutic Discourse: Psychotherapy as Conversation. New York: Academic Press. 
Laitinen, Lea. 1995. Nollapersoona (Zero person construction). Virittäjä 99: 337-358.

Lepper, Georgia and Erhard Mergentahler. 2008. Observing therapeutic interaction in the "Lisa" case. Psychotherapy Research 17(5): 634-644.

Madill, Anna, Sue Widdicombe and Michael Barkham. 2001. "The potential of conversation analysis for psychotherapy research.” The Counseling Psychologist 29: 413-434.

Melander, Helen and Frotjof Sahlström. 2009. "In tow of the blue whale. Learning as interactional changes in topical orientation.” Journal of Pragmatics, 41: 1519-1537.

Mondada, Lorenza and Simona Pekarek Doehler. 2004. "Second Language Acquisition as Situated Practice: Task Accomplishment in the French Second Language Classroom." The Modern Language Journal 88: 501-518.

Muntigl, Peter and Kwok Tim Choi. 2010. "Not remembering as a practical epistemic resource in couples therapy." Discourse Studies 12(3): 331-356.

Muntigl, Peter, Naomi Knight and Ashley Watkins. 2012. "Working to keep aligned in psychotherapy: using nods as a dialogic resource to display affiliation." Language and Dialogue 2(1): 9-27.

Muntigl, Peter. 2013. Resistance in couples counselling: sequences of talk that disrupt progressivity and promote disaffiliation. Journal of Pragmatics 49: 18-37. 
Muntigl, Peter and Horvarth Adam O. 2013. The therapeutic relationship in action: How therapists and clients co-manage relational disaffiliation. Psychotherapy Research (advance online publication). doi.org/10.1080/10503307.2013.807525.

Parsons, Talcott. 1951. The Social System. Glencoe, IL: Free Press.

Pawelczyk, Joanna. 2011. Talk as therapy: Psychotherapy in a Linguistic Perspective. Berlin: Walter de Gruyter.

Peräkylä, Anssi. 2004. "Making links in psychoanalytic interpretations: a conversation analytic view". Psychotherapy Research 14, 289-307.

Peräkylä, Anssi. 2005. “Patients' responses to interpretations. A dialogue between conversation analysis and psychoanalytic theory." Communication \& Medicine 2: 163-176.

Peräkylä, Anssi. 2008. “Conversation analysis and psychoanalysis: Interpretation, affect and intersubjectivity." In Conversation Analysis and Psychotherapy ed. by Anssi Peräkylä, Charles Antaki, Sanna Vehviläinen and Ivan Leudar, 100-119. Cambridge: Cambridge University Press.

Peräkylä, Anssi, Charles Antaki, Sanna Vehviläinen, and Ivan Leudar. 2008. “Analysing Psychotherapy in Practice.” In Conversation Analysis and Psychotherapy ed. by Anssi 
Peräkylä, Charles Antaki, Sanna Vehviläinen, and Ivan Leudar, 5-25. Cambridge: Cambridge University Press.

Peräkylä, Anssi. 2011. "After interpretation: Third position utterances in psychoanalysis.” Research on Language and Social Interaction 44(3): 288-316.

Peräkylä, Anssi. 2012. Conversation Analysis in Psychotherapy. In Blackwell Handbook in Conversation Analysis, ed. by Tanya Stivers and Jack Sidnell, 551-574. Oxford: Blackwell.

Peräkylä, Anssi. 2012. “Die Interaktionsgeschichte einer Deutung.” In Sozialität in Slow Motion: Theoretische und empirische Perspektiven ed. by Ruth Ayass and Christian Meyer, pp. 375-405. Wiesbaden: Springer-Verlag.

Pittinger, Robert.E., Charles F. Hockett, and John J. Danehy.1961. The First Five Minutes. A Sample of Microscopic Interview Analysis. Ithaca, NY: Paul Martineau.

Rae, John. 2008. "Lexical substitution as a therapeutic resource." In Conversation Analysis and Psychotherapy, ed. by Anssi Peräkylä, Charles Antaki, Sanna Vehviläinen, and Ivan Leudar, 62-79. Cambridge: Cambridge University Press.

Ruusuvuori, Johanna and Liisa Voutilainen. 2009. "Comparing affiliating responses to troubles-tellings in different types of health care encounters." In Talk in Interaction: Comparative dimensions, ed. by Markku Haakana, Minna Laakso and Jan Lindström, 206-230). Helsinki: Finnish Literature Society. 
Sacks, Harvey. 1992. Lectures on Conversation. Oxford: Blackwell.

Schegloff, Emanuel A. 2007. Sequence Organization in Interaction: A Primer in Conversation Analysis I. Cambridge: Cambridge University Press.

Scheflen, Albert E. 1973. Communicational Structure. Analysis of a Psychotherapy Transaction. Bloomington: Indiana University Press.

Stern, Daniel. 2004. The Present Moment in Psychotherapy and Everyday Life. New York: W.W. Norton \& Co.

Wampold, Bruce E. 2001. The Great Psychotherapy Debate: Models, Methods, and Findings. Mahwah, NJ: Lawrence Erlbaum.

Vehviläinen, Sanna. 2003. "Preparing and delivering interpretations in psychoanalytic interaction." Text 23 (4): 573-606.

Vehviläinen, Sanna. 2008. "Identifying and managing resistance in psychoanalytic interaction." In Conversation Analysis and Psychotherapy, ed. by Anssi Peräkylä, Charles Antaki, Sanna Vehviläinen and Ivan Leudar, 120-138. Cambridge: Cambridge University Press. 
Vehviläinen, Sanna, Anssi Peräkylä, Charles Antaki, and Ivan Leudar. 2008. "A review of the conversational practices of psychotherapy." In Conversation Analysis and Psychotherapy ed. by Anssi Peräkylä, Charles Antaki, Sanna Vehviläinen and Ivan Leudar, 188-197. Cambridge: Cambridge University Press.

Weiste Elina and Anssi Peräkylä. 2013. “A Comparative Conversation Analytic Study of Formulations in Psychoanalysis and Cognitive Psychotherapy", Research on Language and Social Interaction 46 (4): 299-321

Weiste, Elina and Anssi Peräkylä, forthcoming. "Prosody and empathic communication in psychotherapy interaction." Psychotherapy Research.

Weiste, Elina and Liisa Voutilainen (in preparation). Epistemic relations in psychotherapy: Comparative analysis of therapist's assertions regarding the client's mind in cognitive therapy and psychoanalysis.

Voutilainen, Liisa, Anssi Peräkylä and Johanna Ruusuvuori. 2010. "Recognition and interpretation: Responding to emotional experience in psychotherapy." Research on Language and Social Interaction, 43: 85-107.

Voutilainen, Liisa, Anssi Peräkylä and Johanna Ruusuvuori. 2011. "Therapeutic change in interaction: conversation analysis of a transforming sequence." Psychotherapy Research 21: (3): $348-365$. 
Voutilainen, Liisa. 2012. "Responding to emotion in cognitive psychotherapy". In Emotion in Interaction. ed. by Anssi Peräkylä and Marja-Leena Sorjonen, 235-255. New York: Oxford University Press.

Voutilainen, Liisa, Pentti Henttonen, Mikko Kahri, Niklas Ravaja, Mikko Sams and Anssi Peräkylä. "Therapist's formulations and physiological responses of a patient and a therapist." Paper presented in 13th International Pragmatics Conference 13 September 2013, New Delhi, India. 